\title{
PENGARUH JENIS PENGEMAS TERHADAP RETENSI KAROTEN, SIFAT FISIK DAN KIMIA GULA KELAPA YANG DIPERKAYA MINYAK SAWIT MERAH SELAMA PENYIMPANAN
}

\author{
The Influence of Packaging Types on Carotene Retention, Physics and Chemical Properties of Coconut \\ Palm Sugar Enriched with Red Palm Oil during Storage
}

\author{
Vicencius Prihananto, Hidayah Dwiyanti \\ Jurusan Teknologi Pertanian, Fakultas Pertanian, Universitas Jenderal Soedirman, \\ Jl. Dr. Soeparno, Karangwangkal, Purwokerto 53123 \\ Email: hidayah_unsoed@yahoo.com
}

\begin{abstract}
ABSTRAK
Penambahan minyak sawit merah pada gula kelapa akan berpengaruh terhadap kandungan dan retensi karoten, serta sifat fisik dan sensori produk selama penyimpanan yang juga dipengaruhi oleh jenis pengemas. Penelitian bertujuan untuk mengevaluasi perubahan sifat fisik, kimia dan retensi karoten selama penyimpanan gula kelapa. Gula kelapa yang diperkaya minyak sawit merah dibuat dengan penambahan dua jenis minyak sawit merah (CPO dan RPO) dan jumlah penambahannya $(30 \mathrm{ml}, 60 \mathrm{ml}$ dan $90 \mathrm{ml}) / 10 \mathrm{~L}$ nira kelapa, serta dikemas dengan pengemas tunggal (plastik polypropilene/PP) dan pengemas ganda (plastik PP + kertas coklat). Makin lama penyimpanan terjadi penurunan kekerasan tekstur, retensi dan kadar total karoten, sebaliknya untuk parameter kadar air dan kadar gula reduksi terjadi peningkatan. Setelah disimpan selama 2 bulan, kadar total karoten gula kelapa yang diperkaya karoten dari CPO maupun RPO turun antara 4,89 \% - 49,79 \% dengan kadar karoten antara $703 \mu \mathrm{g} / 100 \mathrm{~g}-1338,3 \mu \mathrm{g} / 100 \mathrm{~g}$. Makin banyak jumlah penambahan CPO maupun RPO, persentase penurunan total karoten selama penyimpanan makin kecil. Penurunan kadar total karoten bulan ke-1 dan ke-2 pada gula kelapa yang diperkaya RPO lebih tinggi (17,48 \% dan $24,48 \%)$ dibandingkan gula CPO (7,47 \% dan $12,95 \%)(\mathrm{p}<0.05)$. Penggunaan pengemas ganda plastik polypropylene dengan kertas coklat (payung) mampu menghambat penurunan total karoten hingga 4,00 \% sampai 6,67 \% lebih baik dibandingkan pengemas tunggal. Makin lama penyimpanan, kadar air produk makin meningkat. Namun demikian hingga penyimpanan selama 2 bulan, kadar air produk pada semua perlakuan masih dalam kisaran standar SNI-01$3743-1995(<10 \%)$, yaitu antara 8,55 \% - 9,94\%.
\end{abstract}

Kata kunci: Minyak sawit merah, retensi karoten, gula kelapa, penyimpanan, pengemas

\begin{abstract}
The addition of red palm oil in palm sugar will affect the content and retention of carotene as well as physical and sensory properties of the product during storage which were also influenced by packaging types. This study aimed to evaluate the changes in physical, chemical and carotene retention during storage of palm sugar. Palm sugar enriched with red palm oil was made by addition of two types of red palm oil (CPO and RPO ) and the amount of the addition $(30 \mathrm{ml}, 60 \mathrm{ml}$ and $90 \mathrm{ml}) / 10 \mathrm{~L}$ coconut sap, after that packed with a single packaging (polypropylene, $\mathrm{PP}$ ) and double packaging (PP + brown paper ) and stored for 2 months. After stored for 2 months, the level of total carotenoids of coconut palm sugar enriched with RPO decreased between 4.99 to $49.79 \%$ with carotene content between $703 \mu \mathrm{g} / 100$ $\mathrm{g}$ up to $13383 \mu \mathrm{g} / 100 \mathrm{~g}$. The decreased level of total carotene in first month and second month storage of coconut palm sugars enriched with RPO was higher $(17.48 \%$ and $24.47 \%$ ) compared to coconut palm sugar enriched with CPO $(7.47 \%$ and $12.95 \%)(\mathrm{p}<0.05)$. The use of double packaging (polypropylene plastic + brown paper) is able to inhibit the decrease in total carotenoid up to $4.00 \%$ to $6.67 \%$, better than the single packaging. The longer the storage, moisture content of product increased. However, after stored up to 2 months, the water content in all treatments was in range of SNI-01-3743-1995 standard (<10\%) which is between $8.55 \%$ up to $9.94 \%$.
\end{abstract}

Keywords: Red palm oil, carotene retention, coconut palm sugar, storage, packaging 


\section{PENDAHULUAN}

Gula kelapa adalah produk pangan yang dibuat dengan cara menguapkan nira kelapa hingga terbentuk massa gula semi padat dan siap cetak. Gula kelapa merupakan komoditas yang digunakan secara luas baik untuk keperluan rumah tangga maupun industri. Salah satu tahapan dalam pengolahan gula kelapa adalah menambahkan minyak sayur (minyak goreng) pada fase lewat jenuh, yang juga disebut fase foaming (pembentukan buih). Penambahan minyak dimaksudkan untuk menurunkan tegangan permukaan buih yang terbentuk, sehingga busa menjadi collapse (pecah)dan terjadi penurunan massa buih (defoaming). Penggunaan minyak sawit merah baik crude palm oil (CPO) maupun red palm oil (RPO) yang kaya akan karoten untuk tahap defoaming, diharapkan akan dihasilkan gula kelapa tinggi karoten dan berpotensi sebagai pangan alternatifuntuk penanggulangan masalah kekurangan vitamin A (KVA).

Hingga saat ini kekurangan vitamin A (KVA) masih menjadi salah satu masalah kesehatan di Indonesia. Hasil survey menunjukkan kasus defisiensi vitamin A sub klinis di Indonesia masih tinggi yang ditunjukkan lebih dari $50 \%$ balita mempunyai kadar retinol serum $<20 \mathrm{mcg} / \mathrm{dl}$ (Depkes, 2003). Data terbaru menunjukkan masih ditemukan kasus xeropthalmia $0,13 \%$ dan indeks retinol serum $14,6 \%$, serta terjadi penurunan cakupan suplementasi vitamin A secara nasional (Bappenas, 2011, Riskesdas, 2010 ). Defisiensi vitamin A seperti halnya zat gizi mikro lainnya akan berdampak pada penurunan kualitas sumberdaya manusia, dan merupakan penyebab terbesar kasus morbiditas dan mortalitas pada anakanak balita dibeberapa negara berkembang (Thurnham dkk., 2003). Berbagai hasil studi menyebutkan bahwa KVA pada bayi dan anak balita dapat menurunkan daya tahan tubuh, meningkatkan resiko kesakitan dan kematian akibat infeksi dan meningkatkan resiko kebutaan (Bappenas 2011; Villamor dan Fawzi 2000; Christian dkk., 2000; Witcher dkk., 2001). Status gizi baik pada anak balita merupakan prasyarat dasar untuk meningkatkan daya saing bangsa karena status gizi akan mempengaruhi tingkat kesehatan fisik dan kecerdasan anak yang akhirnya akan mempengaruhi tingkat produktivitas mereka.

Pemanfaatan gula kelapa yang diperkaya provitamin A bersumber minyak sawit merah untuk mengatasi KVA, merupakan salah satu alternatif intervensi berbasis pangan. Minyak sawit merah mengandung $\beta$-karoten antara 500-700 ppm serta memiliki bioavailabilitas yang lebih baik daripada $\beta$-karoten yang terdapat pada bayam dan wortel (Darnoko dkk., 2002; van het Hof dkk., 2000; Rice dan Burn, 2010) dan telah diuji kemampuannya dalam memperbaiki status vitamin A pada berbagai studi pada manusia (Lietz dkk., 2001; Zagre dkk., 2003; Canfields dkk., 2001; Radhika dkk.,
2003; Zeba dkk., 2006). Selain itu, ketersediaan sawit di Indonesia cukup berlimpah. Produksi minyak sawit mentah tahun 2013 mencapai 28 juta ton. Data terbaru menunjukkan ekspor sawit Indonesia mencapai 15 juta ton per September 2014, meskipun terjadi penurunan nilai ekspor sebesar 1,75\% dibandingkan ekspor tahun sebelumnya (GAPKI, 2014).

Gula kelapa termasuk produk yang mempunyai umur simpan cukup lama, yaitu sekitar satu bulan. Penurunan mutu gula kelapa terutama ditandai dengan perubahan baik sifat fisik (warna dan tekstur), kimia maupun sensorinya. Selama penyimpanan gula kelapa,memungkinkan terjadinya peningkatan kadar air, gula reduksi, aldehid dan keton yang merupakan hasil dari reaksi kerusakan lemak yang memunculkan bau rancid (tengik).Umur simpan gula kelapa dipengaruhi oleh jenis pengemas yang digunakan, yaitu pada kemampuan pengemas melindungi produk dari komponenkomponen disekelilingnya seperti udara (uap air dan $\mathrm{O}_{2}$ ), cahaya dan kontaminan. Suhu penyimpanan juga berpengaruh terhadap umur simpan gula. Penyimpanan pada suhu rendah akan lebih mempertahankan mutu gula dan memperlambat kerusakannya.

Karoten merupakan komponen yang mudah mengalami kerusakan baik isomerisasi maupun oksidasi, bila terpapar oleh oksigen, panas, asam maupun cahaya. Terjadinya isomerisasi maupun oksidasi pada karoten akan mengakibatkan turunnya atau bahkan kehilangan aktivitas vitamin A nya (Gropper dkk., 2009). Oleh karena itu, untuk mempertahankan retensi karoten di dalam gula kelapa, perlu diupayakan teknik pengemasan yang tepat yang mampu mengurangi paparan produk dari cahaya, maupun udara (oksigen).

Penelitian ini bertujuan untuk mengevaluasi jenis pengemas tunggal dan ganda terhadap retensi karoten, perubahan sifat fisik (tekstur) dan kimia gula kelapa yang diperkaya minyak sawit merah selama penyimpanan.

\section{METODE PENELITIAN}

\section{Bahan dan Alat}

Bahan yang digunakan dalam penelitian ini adalah nira kelapa yang berasal dari perajin gula di desa Pejogol, Kecamatan Cilongok Kabupaten Banyumas, crude palm oil (CPO) yang diperoleh dari PT Smart Tbk, red palm oil (RPO) yang diperoleh melalui proses degumming dan netralisasi CPO di laboratorium Technopark IPB, malto dextrin dari toko kimia Bratachem Purwokerto. Bahan untuk analisis kimiawi berkualitas pro analis (Sigma atau Merck) dibeli di toko bahan kimia Setyaguna Bogor, kertas Whatman no 1, alumunium foil, kertas $\mathrm{pH}$ indikator, bahan pengemas plastik polyprpylene, kertas payung (coklat). 
Alat yang digunakan adalah UV/VIS Spektrophotometer merk JENWAY type 505, Neraca analitik merk METTLER type AE 200, Vortex merk PASOLINA type NS 80, refraktometer, shaker, magnetik stirer, thermometer, alat degumming di Technopark Fateta IPB, alat-alat gelas pyrex.

\section{METODE PENELITIAN}

\section{Disain Penelitian}

Rancangan penelitian yang digunakan adalah Rancangan Acak Kelompok (RAK) dengan tiga faktor yaitu: 1) jenis minyak sawit merah (CPO dan RPO), 2) jumlah penambahan minyak sawit merah per 10 liter nira ( $30 \mathrm{ml}, 60 \mathrm{ml}$ dan $90 \mathrm{ml})$, dan3). Jeniskemasan (kemasan tunggal(plastikpolypropylene/ PP) dan kemasan ganda (plastik PP + kertas payung/coklat). Masing-masing perlakuan diulang 2 kali sehingga terdapat 24 unit percobaan. Parameter yang diamati meliputi: kadar total karoten diukur dengan UV-vis spektrofotometer pada $\lambda=445 \mathrm{~nm}$ (AOAC, 2005), kadar $\beta$-karoten diukur dengan HPLC, retensi provitamin A (karoten), persentase penurunan karoten selama penyimpanan, kadar air (grafimetri), kadar gula reduksi (metode Nelson Somogyi), kadar FFA (titrasi), dan tekstur diukur menggunakan penetrometer. Pengamatan dilakukan pada minggu ke-0, minggu ke-4 dan minggu ke8. Untuk mengevaluasi retensi provitamin A (total karoten) digunakan rumus sebagai berikut:

Retensi total karoten $=\underline{\text { Jumlah total karoten produk akhir } \times 100 \%}$ Jumlah karoten awal

Data hasil pengukuran parameter kimia dan fisik dianalisis dengan sidik ragam (ANOVA) pada selang kepercayaan 95\%. Bila terdapat keragaman dilanjutkan dengan uji jarak berganda Duncan (DMRT) .

\section{Pembuatan Gula Kelapa yang Diperkaya Provitamin A dari Minyak Sawit Merah}

Pemurnian nira kelapa. Nira hasil penyadapan disaring untuk memisahkan kotoran (impurities) yang kasar seperti: bunga kelapa (manggar, serangga/semut), selanjutnya dipanaskan hingga mendidih kemudian didinginkan dan disaring kembali menggunakan kain saring (Munyl Switzerland 500 mesh) untuk memisahkan impurities/kotoran yang halus.

Pengolahan gula kelapa dengan modifikasi penambahan minyak sawit merah. Prinsip pembuatan gula kelapa adalah evaporasi nira kelapa hingga fase lewat jenuh. Pada tahap defoaming, dilakukan modifikasi dengan mengganti penggunaan minyak sayur dengan minyak sawit merah dengan jumlah sesuai dengan perlakuan yang dicoba pada penelitian ini. Maltodextrin ditambahkan sebagai stabilizer dengan jumlah $0,01 \%$ terhadap total nira. Penambahan minyak sawit merah dilakukan setelah tercapai fase jenuh. Pemanasan dilanjutkan hingga tercapai end point $\left(\right.$ suhu $\left.=118^{\circ} \mathrm{C}\right)$, pemasakan dihentikan dan dilanjutkan dengan pengadukan secara kontinyu (tahap solidifikasi) hingga massa gula berubah menjadi opaque, kemudian dilakukan pencetakan. Gula yang dihasilkan selanjutnya dikemas sesuai dengan perlakuan yang ditetapkan kemudian disimpan hingga waktu pengamatan yang ditetapkan.

\section{HASIL DAN PEMBAHASAN}

Nilai rerata kadar air dan tekstur gula kelapa pada pengamatan minggu ke 0 , ke- 4 dan ke- 8 disajikan pada Tabel 1. Kadar air gula kelapa pada awal penelitian pada semua kelompok perlakuan relatif sama yaitu berkisar antara 7,52 $8,46 \%$ ( $p>0,05)$. Setelah disimpan selama 2 bulan ( 8 minggu), terjadi peningkatan kadar air antara 8,55 - 9,94\% (meningkat $5,05-22,09 \%$ ) namun secara statistik tidak menunjukkan adanya perbedaan yang nyata.

Tabel 1. Perubahan kadar air dan tekstur selama penyimpanan gula kelapa yang diperkaya CPO dan RPO

\begin{tabular}{lcccccc}
\hline \multirow{2}{*}{ Perlakuan } & \multicolumn{3}{c}{ Kadar air (\%) } & \multicolumn{3}{c}{ Tekstur (mm/g/dtk) } \\
\cline { 2 - 7 } & M0 & M4 & M8 & M0 & M4 & M8 \\
\hline RPO30P1 & 7,80 & 8,88 & 8,90 & 0,0023 & 0,0063 & 0,0071 \\
RPO60P1 & 8,14 & 8,68 & 9,94 & 0,0029 & 0,0057 & 0,0069 \\
RPO90P1 & 7,52 & 8,88 & 9,18 & 0,0034 & 0,0055 & 0,0065 \\
RPO30P2 & 7,80 & 8,63 & 8,55 & 0,0023 & 0,0067 & 0,0073 \\
RPO60P2 & 8,14 & 8,21 & 9,63 & 0,0029 & 0,0059 & 0,0071 \\
RPO90P2 & 7,52 & 8,55 & 8,81 & 0,0034 & 0,0056 & 0,0067 \\
CPO30P1 & 8,22 & 8,74 & 8,90 & 0,0031 & 0,0063 & 0.0076 \\
CPO60P1 & 8,38 & 8,87 & 9,18 & 0,0037 & 0,0069 & 0,007 \\
CPO90P1 & 8,46 & 8,91 & 9,04 & 0,0058 & 0,0075 & 0,0079 \\
CPO30P2 & 8,22 & 8,63 & 8,71 & 0,0031 & 0,0066 & 0,0074 \\
CPO60P2 & 8,38 & 8,79 & 9,02 & 0,0037 & 0,0071 & 0,0076 \\
CPO90P2 & 8,46 & 8,80 & 8,89 & 0,0058 & 0,0078 & 0,0081 \\
\hline
\end{tabular}

Keterangan: $\mathrm{P} 1=$ pengemas tunggal, $\mathrm{P} 2=$ pengemas ganda, $\mathrm{M} 0=$ minggu ke-0, M4= minggu ke-4, M8=minggu ke- 8 ; $(30,60,90)=$ jumlah penambahan CPO maupun RPO dalam10 L nira kelapa. $\mathrm{P}>0.05$

Tabel 1 menunjukkan bahwa kadar air pada semua perlakuan meningkat seiring dengan lama penyimpanan, sebaliknya tekstur gula menurun (semakin lunak). Gula merupakan produk yang bersifat higroskopis karena banyak mengandung gugus hidrofilik $(-\mathrm{OH})$ yang mudah mengikat uap air disekitarnya. Namun demikian hingga penyimpanan 
selama 2 bulan, kadar air produk pada semua perlakuan masih dalam kisaran standar SNI-01-3743-1995 (< $10 \%)$, yaitu antara $8,55-9,94 \%$.

Tekstur merupakan salah satu atribut yang penting untuk mutu gula kelapa. Pada penelitian ini, tekstur gula kelapa lebih banyak dipengaruhi oleh jenis minyak sawit merah yang digunakan dan jumlah penambahannya, sebagaimana ditunjukkan pada Tabel 1. Penambahan CPO maupun RPO yang semakin banyak dapat menurunkan tekstur gula kelapa, hal ini ditunjukkan dengan nilai tekstur (mm/g/dtk) yang meningkat. Penggunaan RPO menghasilkan gula dengan tekstur yang lebih keras dibandingkan CPO $(\mathrm{p}<0.05)$.

Minyak sawit merah terutama tersusun oleh trigliserida (lemak dan minyak). Lemak bersifat sebagai impurities (pengotor) pada pengolahan gula akan menghalangi proses kristalisasi sukrosa, yaitu menghalangi berinteraksinya antar molekul sukrosa pada fase lewat jenuh sehingga menurunkan tekstur gula kelapa. Menurut Tjahjaningsih (1991), komponen komponen impurities yang berpengaruh pada tekstur gula kelapa antara lain protein, lemak, pati, dan gum. Gula yang ditambah dengan CPO mempunyai tekstur yang relatif lebih lunak dibandingkan gula RPO karena pada CPO masih mengandung gum yang selain sebagai pengotor juga bersifat hidrofilik, sehingga mengakibatkan kadar air semakin tinggi dan menurunkan tekstur gula kelapa. Pada Tabel 1 terlihat hubungan antara peningkatan kadar air gula dengan penurunan kekerasan. Crude palm oil (CPO), diperoleh dari proses pengepresan mesokarp buah sawit merah dan klarifikasi, dan masih mengandung gum. Melalui proses degumming dan neutralisasi CPO, akan dihasilkan red palm oil (RPO) ( Morad dkk., 2006).

Selama penyimpanan, tekstur gula kelapa mengalami penurunan yang juga dipengaruhi oleh jenis kemasan yang digunakan. Pada pengamatan mingu ke-4 maupun ke-8, jenis minyak sawit merah dan jenis kemasan memberikan pengaruh yang sangat nyata terhadap tekstur gula kelapa $(\mathrm{p}<0,001)$. Rerata nilai tekstur gula kelapa yang diperkaya CPO dan RPO pada pengamatan 1 bulan penyimpanan adalah 0,0070 dan $0,0059 \mathrm{~mm} / \mathrm{g} / \mathrm{dtk}$ dan pada pengamatan 2 bulan masingmasing adalah 0.0076 dan $0,0069 \mathrm{~mm} / \mathrm{g} / \mathrm{dtk}$. Nilai rerata tekstur pada pengaruh penggunaan pengemas tunggal dan pengemas ganda pada penyimpanan 1 bulan masing-masing adalah 0,066 dan $0,0063 \mathrm{~mm} / \mathrm{g} / \mathrm{dtk}$ dan pada pengamatan 2 bulan adalah 0,0074 dan 0,0071 . Selama 2 bulan penyimpanan, tekstur gula kelapa menurun kekerasannya antara 0,38 - 2,15 kali.

Selama penyimpanan gula kelapa terjadi peningkatan kadar gula reduksi karena terjadinya hidrolisis sukrosa menjadi glukosa dan fruktosa. Perubahan ini dipengaruhi antara lain oleh suhu dan kadar air. Pada pengamatan minggu ke-0, kadar gula reduksi produk pada semua perlakuan relatif sama. Namun, makin lama waktu penyimpanan, kadar gula reduksi gula kelapa makin meningkat yang dipengaruhi oleh jenis minyak sawit merah yang digunakan dan jumlah penambahannya (Tabel 2).

Berdasarkan hasil ANOVA pada selang kepercayaan 95\% menunjukkan bahwa jenis minyak sawit merah berpengaruh terhadap kadar gula reduksi pada pengamatan minggu ke-4 dan minggu ke-8. Adapun jumlah penambahan minyak sawit dan jenis kemasan serta interaksinya tidak berpengaruh nyata, namun jenis dan jumlah penambahan minyak berpengaruh nyata pada nilai FFA. Penambahan CPO pada pembuatan gula kelapa secara nyata menunjukkan nilai kadar gula reduksi yang lebih tinggi dibandingkan RPO masing-masing 2,43 dan 2,31 (\% bk) pada M0, 4,32 dan 3,88 (\% bk) pada M4 dan 4,47 dan 4,05 (\% bk) pada M8 (p>0,05).

Tabel 2. Perubahan kadar gula reduksi dan FFA selama penyimpanan gula kelapa yang diperkaya CPO dan RPO

\begin{tabular}{lcccccc}
\hline & \multicolumn{3}{c}{ Kadar gula reduksi } & \multicolumn{3}{c}{ FFA(\%) } \\
Perlakuan & \multicolumn{9}{c}{ (\% bk) } & & & \\
\cline { 2 - 7 } & M0 & M4 & M8 & M0 & M4 & M8 \\
Jenis minyak & & & & & \\
RPO & 2,31 & $3,88 \mathrm{~b}$ & $4,05 \mathrm{~b}$ & $0,132 \mathrm{~b}$ & $0,142 \mathrm{~b}$ & $0,145 \mathrm{~b}$ \\
$\mathrm{CPO}$ & 2,43 & $4,32 \mathrm{a}$ & $4,47 \mathrm{a}$ & $0,150 \mathrm{a}$ & $0,162 \mathrm{a}$ & $0,163 \mathrm{a}$ \\
\hline Jumlah penambahan minyak sawit merah & & \\
$30 \mathrm{ml}$ & 2,41 & 4,00 & 4,12 & $0,132 \mathrm{~b}$ & $0,137 \mathrm{c}$ & $0,139 \mathrm{~b}$ \\
$60 \mathrm{ml}$ & 2,38 & 4,12 & 4,29 & $0,142 \mathrm{ab}$ & $0,153 \mathrm{~b}$ & $0,155 \mathrm{a}$ \\
$90 \mathrm{ml}$ & 2,31 & 4,17 & 4,38 & $0,152 \mathrm{a}$ & $0,167 \mathrm{a}$ & $0,168 \mathrm{a}$ \\
\hline
\end{tabular}

Interaksi jenis minyak $\mathrm{x}$ jumlah $\mathrm{x}$ jenis pengemas

\begin{tabular}{lllllll} 
RPO30P1 & 2,22 & 3,87 & 3,9 & 0,122 & 0,119 & 0,129 \\
RPO60P1 & 2,41 & 3,86 & 4,03 & 0,132 & 0,139 & 0,144 \\
RPO90P1 & 2,30 & 3,69 & 4,12 & 0,144 & 0,154 & 0,159 \\
RPO30P2 & 2,22 & 3,9 & 4,04 & 0,122 & 0,134 & 0,129 \\
RPO60P2 & 2,41 & 3,91 & 4,05 & 0,132 & 0,149 & 0,149 \\
RPO90P2 & 2,30 & 4,04 & 4,18 & 0,144 & 0,159 & 0,159 \\
CPO30P1 & 2,61 & 3,96 & 4,24 & 0,142 & 0,144 & 0,149 \\
CPO60P1 & 2,36 & 4,32 & 4,46 & 0,152 & 0,159 & 0,164 \\
CPO90P1 & 2,32 & 4,35 & 4,59 & 0,159 & 0,174 & 0,174 \\
CPO30P2 & 2,61 & 4,28 & 4,31 & 0,142 & 0,149 & 0,152 \\
CPO60P2 & 2,36 & 4,42 & 4,6 & 0,152 & 0,164 & 0,164 \\
CPO90P2 & 2,32 & 4,58 & 4,62 & 0,159 & 0,179 & 0,179 \\
\hline
\end{tabular}

Keterangan: $\mathrm{P} 1=$ pengemasan tunggal; $\mathrm{P} 2=$ pengemasan ganda, $\mathrm{M} 0=$ minggu ke- $0, \mathrm{M} 4=$ minggu ke-4, M8=minggu ke- $8 ;(30,60$, $90)$ = jumlah penambahan $\mathrm{CPO}$ maupun $\mathrm{RPO}(\mathrm{ml} / 10 \mathrm{~L}$ nira $)$

Gula kelapa RPO cenderung mempunyai kadar gula reduksi yang lebih rendah dibandingkan gula CPO selama penyimpanan. Hal tersebut kemungkinan berkaitan dengan 
lebih rendahnya kadar air pada gula RPO dibandingkan gula CPO. Kadar air dalam produk akan memicu proses hidrolisis sukrosa menjadi gula-gula reduksi (Belitz dan Grosch, 1999). Tingginya kadar gula reduksi pada gula CPO nampaknya juga berkaitan dengan tingginya tingkat keasaman sebagai akibat lebih tingginya jumlah asam lemak bebas pada gula CPO dibandingkan gula RPO. Adanya asam akan memicu laju inversi sukrosa menjadi gula reduksi (glukosa dan fruktosa) (Belitz dan Grosch, 1999). Pada minggu ke-0, kadar gula reduksi produk berkisar 2,2-2,61\%. Setelah disimpan selama 2 bulan, jumlah gula reduksi meningkat menjadi ratarata antara 3,9-4,62 \%. Kadar gula reduksi produk hingga waktu penyimpanan 2 bulan masih memenuhi standar SNI untuk gula kelapa yaitu $<10 \%$.

Tabel 3. Perubahan kadar total karoten dan persentase penurunan karoten selama penyimpanan gula kelapa yang diperkaya CPO dan RPO

\begin{tabular}{|c|c|c|c|c|c|}
\hline \multirow[t]{2}{*}{ Perlakuan } & \multicolumn{3}{|c|}{ Kadar total karoten $(\mu \mathrm{g} / \mathrm{g})$} & \multicolumn{2}{|c|}{$\begin{array}{c}\text { Penurunan } \\
\text { karoten selama } \\
\text { penyimpanan }(\%)\end{array}$} \\
\hline & M0 & M4 & M8 & 1-bulan & 2-bulan \\
\hline \multicolumn{6}{|c|}{ Jenis minyak } \\
\hline RPO & $33,37 \mathrm{~b}$ & 29,36 & 27,15 & $17,48 \mathrm{a}$ & $24,48 \mathrm{a}$ \\
\hline $\mathrm{CPO}$ & $98,54 \mathrm{a}$ & 92,47 & 86,88 & $7,47 \mathrm{~b}$ & $12,95 \mathrm{~b}$ \\
\hline \multicolumn{6}{|c|}{ Jumlah penambahan sawit merah } \\
\hline $30 \mathrm{ml}$ & $32,01 \mathrm{c}$ & $26,52 \mathrm{c}$ & $23,92 \mathrm{c}$ & $19,80 \mathrm{a}$ & $25,47 \mathrm{a}$ \\
\hline $60 \mathrm{ml}$ & $65,43 \mathrm{~b}$ & $61,22 \mathrm{~b}$ & $59,62 \mathrm{~b}$ & $13,07 \mathrm{~b}$ & $21,97 \mathrm{a}$ \\
\hline $90 \mathrm{ml}$ & 100,43 a & $95,02 \mathrm{a}$ & $87,52 \mathrm{a}$ & 4,55 & $8,71 \mathrm{~b}$ \\
\hline \multicolumn{6}{|c|}{ Jenis pengemas } \\
\hline P1 & 65,82 & 59,62 & 54,51 & $14,54 \mathrm{a}$ & $22,05 \mathrm{a}$ \\
\hline $\mathrm{P} 2$ & 66,09 & 62,53 & 59,53 & $10,41 \mathrm{~b}$ & $15,38 \mathrm{~b}$ \\
\hline \multicolumn{6}{|c|}{ Interaksi jenis minyak $\mathrm{x}$ jumlah $\mathrm{x}$ jenis pengemas } \\
\hline RPO30P1 & 14,34 & 8,61 & 7,03 & 39,36 & 49,79 \\
\hline RPO60P1 & 33,16 & 27,64 & 26,92 & 18,03 & 20,01 \\
\hline RPO90P1 & 52,62 & 46,08 & 41,28 & 12,30 & 21,42 \\
\hline RPO30P2 & 14,34 & 10,60 & 9,10 & 25,80 & 35,71 \\
\hline RPO60P2 & 33,16 & 31,14 & 28,55 & 8,41 & 17,64 \\
\hline RPO90P2 & 52,62 & 52,11 & 50,04 & 0,96 & 4,99 \\
\hline CPO30P1 & 49,68 & 41,28 & 37,20 & 17,22 & 25,40 \\
\hline CPO60P1 & 96,87 & 91,91 & 89,70 & 4,61 & 13,84 \\
\hline CPO90P1 & 14,24 & 140,29 & 124,93 & 5,79 & 15,71 \\
\hline CPO30P2 & 49,68 & 45,59 & 42,35 & 8,40 & 15,04 \\
\hline СРO60P2 & 98,51 & 94,16 & 93,30 & 4,16 & 5,00 \\
\hline СРО90Р2 & 14,24 & 141,60 & 133,83 & 4,66 & 9,88 \\
\hline
\end{tabular}

Keterangan: P1 (pengemas tunggal); P2 (pengemas ganda), M0 (minggu ke0), M4 (minggu ke-4), M8 (minggu ke-8).
Penggunaan CPO (minyak sawit kasar) sebagai sumber provitamin A secara nyata menunjukkan hasil gula dengan kadar total karoten yang lebih tinggi dibandingkan penggunaan RPO (minyak sawit merah). Demikian pula halnya dengan parameter retensi karoten. Tingginya kadar karoten pada gula CPO dibandingkan gula RPO disebabkan karena jumlah total karoten pada CPO lebih tinggi. Hasil pengukuran kadar total karoten CPO dan RPO yang digunakan pada penelitian ini menggunakan metode spektrofotometri adalah 2615,4 ppm dan 2133,6 ppm, sedangkan kandungan $\beta$-karoten (HPLC) berturut turut adalah 464 ppm dan 227 ppm. Beberapa peneliti melaporkan perkiraan kandungan karotenoid dalam RPO, yaitu untuk $\beta$-karoten (HPLC) sekitar 143-314 ppm (Trigueiro dan Penteado, 1996), 237 ppm (You dkk., 2002) dan untuk total karoten (spektrofotometri) adalah $500-700$ ppm (Edem, 2002), dan 211 - 2604 ppm (Noh dkk., 2002).

Makin banyak jumlah penambahan minyak sawit merah, retensi karoten selama penyimpanan gula kelapa semakin baik. Hal ini ditunjukkan dengan persentase penurunan karoten yang semakin kecil (Gambar 1). Penggunaan CPO memperlihatkan retensi karoten yang lebih baik dibandingkan RPO. Kadar total karoten pada pengamatan minggu ke-0 berkisar antara 14,34 -148,24 $\mu \mathrm{g} / \mathrm{g}$. Setelah disimpan selama 1 bulan terjadi penurunan kadar karoten antara 0,96 \% - 39,36 $\%$ dengan kadar total karoten berkisar 8,61 - 141,60 $\mu \mathrm{g} / \mathrm{g}$. Pada 2 bulan penyimpanan, penurunan karoten berkisar antara 4,99 \% - 49,79 \% dengan kadar total karoten antara $7,03-133,83 \mu \mathrm{g} / \mathrm{g}$.

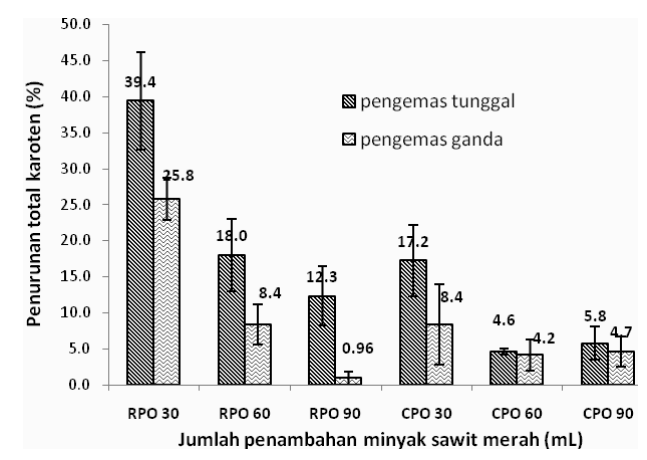

Gambar 1. Penurunan kadar total karoten gula kelapa yang diperkaya CPO dan RPO setelah disimpan selama 1 bulan dengan menggunakan pengemas tunggal dan pengemas ganda

Minyak sawit merah mengandung banyak komponen yang mempunyai aktivitas sebagai antioksidan seperti karoten, likopen, tokoferol dan tokotrienol (Sundram, 2003). Makin banyak jumlah penambahan baik CPO maupun RPO ke dalam formula pembuatan gula kelapa, jumlah komponen antioksidan yang akan melindungi kerusakan karoten secara oksidatifjuga makin banyak. Gum yang terdapat di dalam CPO juga ikut berperan dalam perlindungan terhadap kerusakan 
karoten. Gum mengandung fosfatida yang menstabilkan emulsi formula gula kelapa. Hal itu terlihat pada gula yang ditambah dengan CPO menunjukkan penurunan total karoten selama penyimpanan yang relatif lebih lambat dibandingkan penggunaan RPO.

Penggunaan pengemas yang memadai juga merupakan salah satu upaya untuk mempertahankan mutu suatu produk makanan. Penggunaan pengemas ganda secara nyata menunjukkan penurunan total karoten yang lebih lambat dibandingkan dengan pengemas tunggal. Nilai rerata penurunan total karoten gula yang diperkaya baik CPO maupun RPO pada 1 bulan penyimpanan dengan menggunakan pengemas ganda dan pengemas tunggal masing-masing $10,41 \%$ dan $14,54 \%$, sedangkan pada 2 bulan penyimpanan masing-masing 15,38\% dan 22,05\%. Penggunaan pengemas ganda plastik polypropylene dengan kertas payung mampu menghambat penurunan total karoten antara 4,13\%-6,67 $\%$. Adanya lapisan kertas coklat pada pengemas ganda dapat mengurangi paparan produk oleh cahaya sehingga kerusakan karoten karena proses isomerisasi yang dipicu oleh cahaya dapat diminimalkan. Menurut Caicedo dkk. (2007), paparan cahaya pada penyimpanan puree mangga mengakibatkan terjadinya fotodegradasi beta karoten dan menurunkan retensi beta karoten selama penyimpanan. Lebih lanjut Gropper dkk. (2009), menyebutkan bahwa $\beta$-karoten merupakan komponen yang dapat mengalami kerusakan karena isomerisasi dan oksidasi. Isomerisasi pada karoten dipengaruhi oleh cahaya, panas dan asam. Pada penggunaan pengemas tunggal, plastik hanya mampu menghambat kerusakan secara oksidatif dengan cara mengurangi paparan produk terhadap oksigen, namun kerusakan karena isomerisasi yang dipicu oleh paparan cahaya tidak dapat dihindarkan.

\section{KESIMPULAN}

Jenis pengemas dan jumlah penambahan CPO maupun RPO berpengaruh terhadap kadar dan penurunan total karoten selama penyimpanan gula kelapa. Pengemas ganda plastik plastik polypropylene dan kertas coklat lebih mampu menghambat penurunan karoten gula kelapa baik yang ditambah CPO maupun RPO selama penyimpanan dibandingkan kemasan tunggal. Penurunan kadar total karoten gula kelapa RPO setelah disimpan selama 1 bulan dan 2 bulan lebih tinggi, yaitu 17,48 \% dan 24,48\% dibandingkan gula kelapa CPO, yaitu 7,47 \% dan 12,95\% $(\mathrm{p}<0,05)$.

\section{UCAPAN TERIMA KASIH}

Ucapan terima kasih disampaikan kepada Departemen Pendidikan Tinggi yang telah memberikan bantuan berupa dana penelitian melalui DIPA Universitas Jenderal Soedirman No.: DIPA-023.04: 189899/2013 Tgl. 5 Desember 2012 revisi kedua Tgl. 1 Mei 2013.

\section{DAFTAR PUSTAKA}

Al-Saqer, J.M., Sidhu, J.S., Al-Hoot, S.N., Al-Amiri, H.A., Al-Othman, A., Al-Haji, A., Ahmed, N., Mansour, I.B. dan Minal, J. (2004). Developing functional foods using red palm olein, tocopherols and tocotrienols. Food Chemistry 85: 579-583.

AOAC (2005). Association of Official Analytical Chemist. Official Methods of Analysis of the Association of Official Analytical Chemistry $15^{\text {th }}$ ed. AOAC Inc. Arlington.

Aziz, A.A. (2006). Development of HPLC Analysis for Detection of Lycopene in Tomato and Crude Palm Oil. Tesis. Faculty of Chemical Engineering and Natural Resources. University College of Engineering and Tecnology Malaysia, Malaysia.

Bappenas (2011). menghantarkan vitamin A secepatnya kepada anak balita sebagai upaya pencegahan dan penanggulangan kurang vitamin A. Semiloka Pencegahan dan Penanggulangan Kurang Vitamin A di Indonesia. Jakarta, 19 Agustus 2011.

Belitz, H.D. dan Grosch, W. (1999). Food Chemistry. Springer. Germany.

Benade, A.S. (2013). Red palm oil carotenoids. Potential role in disease prevention. Dalam: Watson, R.A. dan Preedy, V.R., editor. Bioactive Food as Interventions for Cardiovascular Disease, hal. 333-343. Elsevier. London.

Bester, D., Esterhuyse, A.J., Truter, E.J. dan van Royen, J. (2010). Cardiovascular effects of edible oil: a comparison between four popular edible oils. Nutrition Research Review 23: 334-348.

Caicedo, A.L.V., Schilling, S., Carle, R. dan Neydhart, S. (2007). Impact of packaging and storage conditions on colourand $\beta$-carotene retention of pasteurized mango puree. European Food Res Technology 224: 581-590.

Canfield, L.M., Kaminsky, R.G., Taren, D.I., Shaw, E. dan Sander, J.K. (2001). Red palm oil in the maternal diet increases provitamin A carotenoids in breast milk and serum of the mother-infant dyad. European Journal of Nutrition 40: 30-38.

Darnoko, D., Siahaan, D., Nuryanto, E., Elisabeth, J., Erningpraja, L., Tobing, P.L., Naibaho, P.M. dan 
Haryati, T. (2002). Teknologi Pengolahan Kelapa Sawit dan Produk Turunannya. Pusat Penelitian Kelapa Sawit, Medan.

Edem, D.O. (2002). Palm oil: biochemical, physiological, nutritional, hematological and toxicological aspect: a review. Palnt Food Humaniora Nutrition 57: 319-341.

El-Hadad, N., Abou-Gharbia, H.A., El-Aal, M.H. dan Youssef, M.M. (2010). Red palm olein: characterization and utilization in formulating novel functional biscuits. Journal American of Oil Chemistry 87: 295-304.

GAPKI (2014). Gabungan Pengusaha Kelapa Sawit Indonesia. http://www.gapki.or.id. [12 Maret 2013].

Gropper, S.S., Smith, J.L. dan Groff, J.L. (2009). Advanced Nutrition and Human Metabolism. $5^{\text {th }}$ ed. Wadsworth, Cengange Learning, Canada.

Van het Hof, K.H., West, C.E., Weststrate, J.A. dan Hautvast, J.G.A.J. (2000). Dietary factors that affect the bioavailability of carotenoids. Journal of Nutrition 130: 503-506.

Lietz, G., Henry, C.J.K., Mulokozi, G., Mugyabuso, J.K.L., Ballart, A., Ndossi, G.D., Lorri, W. dan Tomkins, A. (2001). Comparison of the effects of supplemental red palm oil and sunflower oil on maternal vitamin A status. American Journal of Clinical Nutrition 74: 501-509.

Morad, N.A., Aziz, M.K.A. dan Rohani, M.Z. (2006). Processing Design in Degumming and Bleaching of Palm Oil. Center of Lipids Engineering and Applied Research. University Technology, Malaysia

Noh, A., Rajanaidu, N., Kushairi, A., Mohd Rafii, Y., MohdDin, A., Mohammad, I. dan Saleh, G. (2002). Variability in fatty acid composition, iodine value and carotene content in the MPOB oil palm germplasm collection from Angola. Journal of Oil Palm Research 14: 18-23.

Radhika, M.S., Bhaskaram, P., Balakrishna, N. dan Ramalakshmi, B.A. (2003). Red palm oil supplementation: A feasible diet-based approach to improve the vitamin A status of pregnant women and their infants. Food and Nutrition Bulletin 24(2): 208217.
Rice, A.L., Burns, J.B. (2010). Moving from efficacy to effectiveness: Red palm oil's Role in preventing vitamin A deficiency. Journal of American Nutrition 29(3): 302S-313S.

Setyaningsih, D., Apriyantono, A. dan Puspita, M.S. (2010). Analisis Sensori untuk Industri Pangan dan Agro. IPB Press, Bogor.

Sundram, K., Sambanthamurthi, R. dan Tan, Y.A. (2003). Palm fruit chemistry and nutrition. Asia Pacific Journal of Clinical Nutrition 12: 355-362.

Tjahjaningsih, J. (1991). Penjajagan Jangkauan Harga dan Kesukaan Konsumen Terhadap Gula Cetak dan Gula Serbuk Nira Kelapa. Laporan penelitian. Lembaga Penelitian dan Pengabdian Kepada Masyarakat (LPPM). Universitas Jenderal Soedirman, Purwokerto.

Triguero, I.N. dan Penteado, Mde. V. (1996). Stereochemical isomers composition and vitamin A value of Brazilian palm oils. Arch Latinoam Nutrition 46: 334-337.

Thurnham, D.I., Mc, Gabe, Northrop-Clewes, C.A. dan Nestel, P. (2003). Effect of subclinical infection on plasma retinol concentrations and assessment of prevalence of vitamin A deficiency: Meta Analysis. The Lancet 362: 2052-2058.

You, C.S., Parker, R.S. dan Swanson, J.E. (2002). Bioavailability and vitamin A value of carotenes of red palm oil assessed by an extrinsic isotope reference method. Asia Pacific Journal of Clinical Nutrition 11(Supplement 7): S438-S442.

Zeba, N.A., Martin, P.Y., Issa, S.T. dan Delisle, H.F. (2006). The positive impact of red palm oil in school meals on vitamin A status: study in Burkina Faso. Nutrition Journal 5(17): 1-10. 